\author{
'고체중' 출하돈의 성장효율, 도체 품질 특성 및 수익성 \\ 박만종*,** . 하덕민** . 신호원** . 이상훈*** - 김원기*** . 하승호*** . 양한술*,** . 정진연*** . \\ 주선태*,** . 이철영** \\ 경상대학교 동물자원과학부*, 진주산업대학교 동물생명산업센터**, 부경양돈농협***
}

\title{
Growth Efficiency, Carcass Quality Characteristics and Profitability of 'High'-Market Weight Pigs
}

\author{
M. J. Park*,**, D. M. Ha**, H. W. Shin**, S. H. Lee***, W. K. Kim***, S. H. Ha***, \\ H. S. Yang*,**, J. Y. Jeong*,**, S. T. Joo*,** and C. Y. Lee**
}

Division of Animal Science, Gyeongsang National University*, Regional Animal Industry Center, Jinju National University**, Pusan and Kyungnam Swine Farms Association***

\begin{abstract}
Domestically, finishing pigs are marketed at $110 \mathrm{~kg}$ on an average. However, it is thought to be feasible to increase the market weight to $120 \mathrm{~kg}$ or greater without decreasing the carcass quality, because most domestic pigs for pork production have descended from lean-type lineages. The present study was undertaken to investigate the growth efficiency and profitability of 'high'-market wt pigs and the physicochemical characteristics and consumers' acceptability of the high-wt carcass. A total of 96 (Yorkshire $\times$ Landrace) $\times$ Duroc-crossbred gilts and barrows were fed a finisher diet ad laibtum in 16 pens beginning from 90-kg BW, after which the animals were slaughtered at $110 \mathrm{~kg}$ (control) or 'high' market wt (135 and 125kg in gilts \& barrows, respectively) and their carcasses were analyzed. Average daily gain and gain:feed did not differ between the two sex or market wt groups, whereas average daily feed intake was greater in the barrow and high market wt groups than in the gilt and 110-kg market wt groups, respectively $(\mathrm{P}<0.01)$. Backfat thickness of the high-market wt gilts and barrows corrected for 135 and 125-kg live wt, which were 23.7 and $22.5 \mathrm{~mm}$, respectively, were greater $(\mathrm{P}<0.01)$ than their corresponding 110-kg counterparts (19.7 \& $21.1 \mathrm{~mm})$. Percentages of the trimmed primal cuts per total trimmed lean $(\mathrm{w} / \mathrm{w})$, except for that of loin, differed statistically $(\mathrm{P}<0.05)$ between two sex or market wt groups, but their numerical differences were rather small. Crude protein content of the loin was greater in the high vs. 110-kg market group $(\mathrm{P}<0.01)$, but crude fat and moisture contents and other physicochemical characteristics including the color of this primal cut were not different between the two sexes or market weights. Aroma, marbling and overall acceptability scores were greater in the high vs. $110-\mathrm{kg}$ market wt group in sensory evaluation for fresh loin $(\mathrm{P}<0.01)$; however, overall acceptabilities for cooked loin, belly and ham were not different between the two market wt groups. Marginal profits of the 135- and 125-kg high-market wt gilt and barrow relative to their corresponding 110-kg ones were approximately $-35,000$ and 3,500 wons per head under the current carcass grading standard and price. However, if it had not been for the upper wt limits for the A- and B-grade carcasses, marginal profits of the high market wt gilt and barrow would have amounted to 22,000 and 11,000 wons per head, respectively. In summary, 120 125-kg market pigs are likely to meet the consumers' preference better than the $110-\mathrm{kg}$ ones and also bring a profit equal to or slightly greater than that of the latter even under the current carcass grading standard. Moreover, if only the upper wt limits of the A- \& B-grade carcasses were removed or increased to accommodate the high-wt carcass, the optimum market weights for the gilt and barrow would fall upon their target weights of the present study, i.e. 135 and $125 \mathrm{~kg}$, respectively.

(Key words : Finishing pig, Growth, Market weight, Carcass, Sensory evaluation)
\end{abstract}

Corresponding author : C. Y. Lee, Regional Animal Industry Center, Jinju National University, Jinju 660-758 Tel: 055-751-3285, Fax: 055-753-4422, E-mail: cylee@jinju.ac.kr 


\section{I. 서 론}

비육돈의 출하체중은 육질은 물론 양돈업의 수익성에도 크게 영향을 미치는 요인이다(이 등, 2006). 출하체중은 품종 및 사양프로그램 등과 같은 내적인 요인과 소비자 집단의 문화, 전통 및 기호 성향은 물론 도축-가공업자의 요구 등 다양한 외적 요인에 따라 결정된다 (Kim 등, 2005). 세계적으로 지난 20 30년 동 안 비육돈의 출하체중은 $5 \sim 20 \mathrm{~kg}$ 증가하였는 데 이는 무엇보다도 종돈 자체가 적육 생산을 극대화하는 방향으로 육종되어 재래의 돼지에 비해 현대의 비육돈은 체중 증가에 따른 지방 침적의 증가 정도가 저하되어 일정 한도까지는 출하체중이 증가할수록 돈육의 생산원가가 저 하되기 때문이다. 현재 세계적으로 비육돈의 출하체중은 주로 국가에 따라 $90 \sim 140 \mathrm{~kg}$ 범위 의 수치를 나타내고 있고, 미국의 경우는 주에 따라 $92 \sim 137 \mathrm{~kg}$ 의 분포를 보이고 있다(NASS, 2006).

국내에서 사용되고 있는 대부분의 종돈은 구 미 지역에서 도입된 적육형일 뿐만 아니라 국 내 돈육 소비자는 구미의 소비자에 비해 삼겹 살과 같이 지방 함량이 높은 부위를 선호하는 등 돼지지방에 대해 관대하여 출하체중을 높게 유지할 수 있는 잠재력이 크다. 그러나 국내 비육돈의 출하체중은 2003년 이후 $110 \mathrm{~kg}$ 수준 에 정체되어 구미 지역보다 $5 \sim 20 \mathrm{~kg}$ 낮은 수 치를 나타내고 있어 앞으로 국내 비육돈의 출 하체중을 높일 수 있는 여지가 많다. 이러한 점에 착안하여 본 연구진은 선행연구(이 등, 2006)에서 경남지역에서 가장 일반적으로 사육 되고 있는 계통의 비육돈을 $110 \mathrm{~kg}$ 대비 $130 \mathrm{~kg}$ 까지 비육 - 도축하여 도체특성 및 경제성을 분 석하여 다음과 같은 주요결과를 얻었다. 본 지 역의 대표적인 비육돈은 적육형이기 때문에 생 체중 $110 \mathrm{~kg}$ 대비 $130 \mathrm{~kg}$ 출하돈은 사료섭취량 과 등지방두께는 다소 증가하고 사료효율은 다 소 감소하였으나 일당증체량은 저하되지 않았 고, 암퇘지와 거세돼지의 등지방두께는 각각 다소 얇게 \& 다소 두껍게 평가되었으며, 도체 품질의 척도가 되는 근육의 이화학적 특성에는
차이가 없었다. 수익성 면에 있어서는 $110 \mathrm{~kg}$ 출하돈 대비 $130 \mathrm{~kg}$ 출하돈은 두당 약 20,000 원 의 손실이 발생하는데 이는 도체품질과는 관계 없이 거의 전적으로 A \& B 등급의 한계도체중 초과로 인한 도체등급 저하 때문에 발생한 손 실로서 만일 이들 등급의 도체중 상한선이 철 폐되기만 한다면 $130 \mathrm{~kg}$ 출하돈이 $110 \mathrm{~kg}$ 출하 돈보다 훨씬 더 경제성이 높을 것으로 예측되 었다. 또한 이와 같은 결과를 토대로 본 연구 진은 현행 도체등급 판정 기준을 무시한 암퇘 지와 거세돼지의 적정 출하체중은 각각 135 \& $125 \mathrm{~kg}$ 수준이고 이때 암퇘지와 거세돼지의 등 지방두께 예측치는 각각 $22.5 \& 24.0 \mathrm{~mm}$ 라는 결론을 내린 바 있다. 따라서 본 연구는 선행 연구의 결론과 같이 암퇘지와 거세돼지를 각각 $135 \& 125 \mathrm{~kg}$ 까지 비육·도축했을 때 성장효 율, 도체의 품질 관련 이화학적 특성과 관능적 수용성 및 경제성을 분석하여 기 발표된 결론 의 타당성을 확인 - 검증하고자 수행되었다.

\section{ㅍ. 재료 및 방법}

\section{1. 공시돈}

본 실험은 2[성; 암 vs. 거세] $\times$ 2[출하체중; $110 \mathrm{~kg}$ vs. 고체중 $\{135 \mathrm{~kg}$ (암) 혹은 $125 \mathrm{~kg}$ (거세)] 'factorial' 실험설계 하에 경남 진주시 소재 "T" 농장에서 수행되었다. 생체중 약 $90 \mathrm{~kg}$ 의 (Yorkshire $\times$ Landrace) $\times$ Duroc 3 원 교잡종 암퇘지와 거세 돼지 각각 48 두씩을 돈방당 6 두씩 16 돈방 $\left(9 \mathrm{~m}^{2} /\right.$ 돈방; $1.5 \mathrm{~m}^{2}$ /두)에 임의배치하고 공시돈은 전술 한 바(이 등, 2006)와 같이 조단백질, lysine 및 가소화에너지 함량이 각각 $15.5 \%, 0.9 \%$ 및 $3,200 \mathrm{kcal} / \mathrm{kg}$ 인 사료와 물을 자유로이 섭취하도 록 하였다.

\section{2. 도체분석}

당초에 계획되었던 생체중에 도달한 공시돈 은 주당 1 회씩 부경양돈농협 축산물공판장에 출하- 도축하여 도체중과 등지방두께 등을 측 정하고 도체는 $4^{\circ} \mathrm{C}$ 에서 24 시간 냉각시킨 후 전 
술한 바(Lee 등, 2002; 이 등, 2006)와 같이 배 최장근의 명도(L*) 및 적색도(a*) (CIE, 1978), 수분, 조단백질 및 지방 함량(AOAC, 1990)을 측정하고, 지방을 추출하여(Folch 등, 1957) gas chromatography 방법(Zanardi 등, 2000)으로 지방 산 조성을 분석하였다.

실험구당 12 두씩 총 48 두의 공시돈에 대해서 는 냉각후 7 개의 부분육을 절단하여 무게를 측 정하고 총 부분육 중량 대비 각각의 부분육 중 량 비율을 계산하였다. 배최장근(등심)의 신선 육 및 가열육에 대해서는 본 연구진의 실험실 에서 잘 훈련된 검사요원 10 명을 선발하여 각 실험구별 9점 척도법으로 육색, 향, 불쾌취, 육 즙삼출도, 다즙성, 연도, 상강도 및 전체적인 기호도를 평가하였다[1점\{매우 나쁘거나 낮음 (“extremely bad or slight”) $\rightarrow$ 9점 $\{$ 매우 좋거나 강함(“extremely good or much”)\}](진 등, 2007). 삼겹살 신선육의 지방점수 및 삼겹살과 뒷다리 의 가열육에 대한 관능평가는 실험구당 3 두씩 등심에 대한 평가와 같은 방법으로 실시하였다.

\section{3. 통계분석}

모든 변수는 SAS(1996)의 General Linear Model Procedure를 이용하여 분석하였다. 이 때 사료섭취량과 사료효율은 돈방을 실험단위로
하고, 관능평가 변수를 포함한 그 외의 모든 변수에 대해서는 공시돈[관능평가의 경우 성 $\times$ 출하체중에 'nested']을 실험단위로 하여 성, 출 하체중 및 성 $\times$ 출하체중 간의 상호작용의 유 의성 여부를 검정하였다.

\section{4. 수익성 분석}

$135 \mathrm{~kg}$ '고체중' 암퇘지와 $125 \mathrm{~kg}$ 고체중 거세 돼지 출하의 수익성은 각각의 성에서 $110 \mathrm{~kg}$ 비 육돈 대비 고체중 비육돈을 출하했을 때 발생 하는 판매대금 증가분(한계수입)에서 추가로 발 생하는 비용(한계비용; 사료비 \& 기타 생산비) 을 감하여 산출한 순수익 증가(한계수익)를 추 산함으로써 분석하였다(이 등, 2006).

\section{III. 결 과}

\section{1. 성장효율}

본 실험에 쓰인 공시돈의 실험구별 평균 개 시체중은 $88 \sim 91 \mathrm{~kg}$ 의 범위로서 4 실험구[2성 (암 vs. 거세) $\times$ 2출하제중 $(110 \mathrm{~kg}$ vs. '고체중' $\{$ $135 \mathrm{~kg}$ (암) 혹은 $125 \mathrm{~kg}$ (거세)\}]간 유의차가 없었 다(Table 1). 그러나 종료체중에 있어서는 $110 \mathrm{~kg}$

Table 1. Growth performance of finishing gilts and barrows slaughtered at 'high' market weights vs. $110 \mathrm{~kg}$

\begin{tabular}{|c|c|c|c|c|c|c|}
\hline \multirow{2}{*}{ Item } & \multicolumn{2}{|c|}{ Gilts } & \multicolumn{2}{|c|}{ Barrows } & \multirow{2}{*}{$\begin{array}{c}\text { Pooled } \\
\text { SE }\end{array}$} & \multirow{2}{*}{ Significance } \\
\hline & Lo $\mathrm{MW}^{\mathrm{a}}$ & Hi MW $^{\mathrm{b}}$ & Lo $\mathrm{MW}^{\mathrm{a}}$ & Hi MW $^{\mathrm{b}}$ & & \\
\hline Initial wt, kg & 88.0 & 90.7 & 87.8 & 89.2 & 1.1 & \\
\hline Final wt, kg & 109.0 & 132.0 & 109.7 & 126.0 & 0.9 & Sex**, MW ${ }^{* *}, \operatorname{Sex} \times \mathrm{MW}^{* *}$ \\
\hline $\mathrm{ADG}, \mathrm{kg}$ & 0.77 & 0.80 & 0.85 & 0.79 & 0.03 & \\
\hline $\mathrm{ADFI}^{\mathrm{c}}, \mathrm{kg}$ & 2.97 & 3.49 & 3.32 & 3.54 & 0.07 & $\mathrm{Sex}^{* *}, \mathrm{MW}^{* *}$ \\
\hline Gain:feed ${ }^{c}$ & 0.213 & 0.221 & 0.246 & 0.220 & 0.010 & \\
\hline Backfat $^{\mathrm{d}}, \mathrm{mm}$ & 19.7 & 23.7 & 21.1 & 22.5 & 0.7 & $\mathrm{MW}^{* *}$ \\
\hline
\end{tabular}

${ }^{\mathrm{a}, \mathrm{b}}$ Low and high market weights, respectively. Data are means of 24 animals, unless indicated otherwise.

c Pen was the experimental unit ( $\mathrm{n}=4$ in each sex $\times$ MW combination).

d Adjusted for 110-kg live weight for Lo MW and for 135- and 125-kg live weights for Hi-MW gilts and barrows, respectively.

$* \mathrm{P}<0.05 ; * * \mathrm{P}<0.01$. 
출하 구는 암퇘지 $(109.0 \mathrm{~kg})$ 와 거세돼지 $(109.7$ $\mathrm{kg})$ 간 차이가 없었으나 고체중 암퇘지 $(132 \mathrm{~kg})$ 와 거세돼지 $(126 \mathrm{~kg})$ 는 두 성간 차이가 있어 $(\mathrm{P}<0.01)$ 전체적으로 본 변수는 성, 출하체중 및 성 $\times$ 출하체중간 상호작용의 영향이 컸다 $(\mathrm{P}<0.01)$. 일당증체량에서는 성 및 출하체중간 차이가 없었고, 이들 두 개의 고정오차간 상호 작용도 없었다. 일당사료섭취량은 거세돼지가 암퇘지보다 높았고(3.43 vs. $3.23 \mathrm{~kg} ; \mathrm{SE}=0.05 \mathrm{~kg}$; $\mathrm{P}<0.01)$, 고체중 출하 구가 $110 \mathrm{~kg}$ 출하 구보다 높았으나(3.51 vs. $3.15 \mathrm{~kg} ; \mathrm{SE}=0.05 \mathrm{~kg} ; \mathrm{P}<0.01)$, 사료효율에서는 두 성 및 출하체중간 차이가 없었다. 표적출하체중 $(110,125$, 혹은 $135 \mathrm{~kg})$ 에 보정된 등지방두께는 고체중 출하구가 $110 \mathrm{~kg}$ 출하구보다 높았으나(23.1 vs. $20.4 \mathrm{~mm}$; SE $=0.5$ $\mathrm{mm} ; \mathrm{P}<0.01)$ 두 성간의 차이는 없었다.

\section{2. 도체 특성}

도체중은 성 및 출하체중간 큰 차이가 있었 을 뿐만 아니라 $(\mathrm{P}<0.01)$ 이들 2 개 고정오차간의 상호작용도 있었는데 $(\mathrm{P}<0.01)$ 이는 거의 전적으 로 고체중 암퇘지와 거세돼지의 출하체중 차이 에 기인하였다(Table 2). 도체율은 암퇘지가 거 세돼지보다 높았고(75.2 vs. 74.2\%; $\mathrm{SE}=0.3 \%$; $\mathrm{P}<0.01)$, 고체중 출하 구(75.1\%)가 $110 \mathrm{~kg}$ 출하 구(74.3\%)보다 높았다 $(\mathrm{P}<0.05)$. 총 정육량은 도 체중에서와 같이 고체중 암퇘지와 거세돼지의 출하체중 차이로 인하여 성, 출하체중 및 이들 간 상호작용의 영향이 컸다 $(\mathrm{P}<0.01)$. 도체중 대 비 7대 부분육의 총중량 비율은 암퇘지가 거세 돼지보다 높았고(44.0 vs. $42.9 \%$; $\mathrm{SE}=0.4 \%$; $\mathrm{P}<0.05)$, 고체중 출하 구(44.3\%)가 $110 \mathrm{~kg}$ 출하 구(42.5\%) 보다 높았다 $(\mathrm{P}<0.01)$. 한편 총부분육 중량 대비 개별 부분육 중량 비율에 있어서는 등심을 제외한 모든 부분육에서 성 혹은 출하 체중의 효과가 있었으나 $(\mathrm{P}<0.05)$, 수치상으로

Table 2. Yields of primal cuts of gilts and barrows slaughtered at 'high' market weights vs. $110 \mathrm{~kg}$

\begin{tabular}{|c|c|c|c|c|c|c|}
\hline \multirow{2}{*}{ Item } & \multicolumn{2}{|c|}{ Gilts } & \multicolumn{2}{|c|}{ Barrows } & \multirow{2}{*}{$\begin{array}{l}\text { Pooled } \\
\text { SE }\end{array}$} & \multirow{2}{*}{ Significance } \\
\hline & Lo $\mathrm{MW}^{\mathrm{a}}$ & Hi MW ${ }^{b}$ & Lo $\mathrm{MW}^{\mathrm{a}}$ & $\mathrm{Hi} \mathrm{MW}^{\mathrm{b}}$ & & \\
\hline Carcass wt, kg & 81.3 & 99.3 & 81.2 & 88.9 & 1.0 & Sex**, MW**, MW×Sex** \\
\hline Dressing, \% & 74.6 & 75.9 & 74.0 & 74.4 & 0.4 & Sex ${ }^{* *}, \mathrm{MW}^{*}$ \\
\hline Total lean ${ }^{\mathrm{ce}}$, $\mathrm{kg}$ & 46.4 & 59.1 & 45.9 & 54.6 & 0.6 & $\mathrm{Sex}^{* *}, \mathrm{MW}^{* *}, \mathrm{Sex} \times \mathrm{MW}^{* *}$ \\
\hline Yield of lean ${ }^{\mathrm{d}, \mathrm{e}}, \%$ & 43.1 & 44.9 & 41.9 & 43.8 & 0.5 & Sex*, MW** \\
\hline \multicolumn{7}{|c|}{ Yield percentage of the primal cut ${ }^{\mathrm{e}}$} \\
\hline Picnic & 16.3 & 15.9 & 16.3 & 16.0 & 0.2 & $\mathrm{MW}^{*}$ \\
\hline Shoulder & 8.3 & 9.0 & 8.5 & 9.0 & 0.2 & $\mathrm{MW}^{*}$ \\
\hline Loin & 13.3 & 13.7 & 13.1 & 13.5 & 0.2 & \\
\hline Tenderloin & 1.8 & 1.7 & 1.8 & 1.7 & 0.05 & MW* \\
\hline Rib & 7.6 & 7.8 & 8.1 & 8.0 & 0.2 & Sex* \\
\hline Belly & 19.8 & 20.0 & 20.6 & 20.5 & 0.3 & Sex* \\
\hline Ham & 32.8 & 31.9 & 31.6 & 31.3 & 0.3 & Sex* \\
\hline Total & 100.0 & 100.0 & 100.0 & 100.0 & - & - \\
\hline $\begin{array}{ll}\text { a } & \text { Low market weigh } \\
\text { b } & \text { High market weigh } \\
\text { a,b } & \text { Data are means of } \\
\text { c } & \text { Total weight of the } \\
\text { d } & \text { Total lean weight } \\
\text { e } & \text { Data are means of } \\
* \mathrm{P}<0.05 ; * * \mathrm{P}<0.01 .\end{array}$ & $\begin{array}{l}\text {; } 109.0 \text { and } \\
\text { t; } 132.0 \text { anc } \\
24 \text { animals, } \\
\text { seven trim } \\
\text { divided by c } \\
12 \text { animals. }\end{array}$ & $\begin{array}{l}109.7 \mathrm{~kg} \text { or } \\
126.0 \mathrm{~kg} \text { o } \\
\text { unless ind } \\
\text { med primal } \\
\text { carcass weig }\end{array}$ & $\begin{array}{l}\text { averages in } \\
\text { averages in } \\
\text { ated otherwi } \\
\text { uts. }\end{array}$ & $\begin{array}{l}\text { gilts and be } \\
\text { gilts and b } \\
\text { se. }\end{array}$ & $\begin{array}{l}\text { arrows, re } \\
\text { arrows, re }\end{array}$ & $\begin{array}{l}\text { pectively. } \\
\text { spectively. }\end{array}$ \\
\hline
\end{tabular}


Table 3. Physicochemical characteristics of the longissimus muscle (loin) of gilts and barrows slaughtered at 'high' market weights vs. $110 \mathrm{~kg}$

\begin{tabular}{|c|c|c|c|c|c|c|}
\hline \multirow{2}{*}{ Item } & \multicolumn{2}{|c|}{ Gilts } & \multicolumn{2}{|c|}{ Barrows } & \multirow{2}{*}{$\begin{array}{l}\text { Pooled } \\
\text { SE }\end{array}$} & \multirow{2}{*}{ Significance } \\
\hline & Lo $\mathrm{MW}^{\mathrm{a}}$ & Hi MW ${ }^{b}$ & Lo $\mathrm{MW}^{\mathrm{a}}$ & $\mathrm{Hi} \mathrm{MW}^{\mathrm{b}}$ & & \\
\hline $\mathrm{pH}-24 \mathrm{~h}$ & 5.83 & 5.61 & 5.77 & 5.67 & 0.05 & $\mathrm{MW}^{* *}$ \\
\hline WHC, \% & 62.6 & 65.4 & 61.6 & 59.3 & 2.4 & \\
\hline \multicolumn{7}{|l|}{ Muscle color } \\
\hline CIE L* & 47.8 & 48.5 & 49.7 & 49.2 & 0.8 & \\
\hline CIE $a^{*}$ & 6.53 & 7.03 & 6.64 & 7.01 & 0.26 & \\
\hline \multicolumn{7}{|c|}{ Chemical composition, \% } \\
\hline Moisture & 74.9 & 74.6 & 74.7 & 74.6 & 0.2 & \\
\hline Crude fat & 1.63 & 1.66 & 2.02 & 1.68 & 0.14 & \\
\hline Crude protein & 20.87 & 22.28 & 20.76 & 22.38 & 0.15 & MW** \\
\hline \multicolumn{7}{|c|}{ Composition of fatty acids, \% } \\
\hline 14:0 & 1.39 & 1.47 & 1.61 & 1.52 & 0.08 & \\
\hline 16:0 & 25.56 & 24.82 & 26.14 & 24.82 & 0.26 & $\mathrm{MW}^{* *}$ \\
\hline 18:0 & 12.40 & 12.72 & 13.40 & 12.46 & 0.52 & \\
\hline $16: 1$ & 3.59 & 3.65 & 3.72 & 3.80 & 0.14 & \\
\hline 18:1 & 41.07 & 43.64 & 40.80 & 44.21 & 0.52 & $\mathrm{MW}^{* *}$ \\
\hline 18:2 & 12.76 & 10.76 & 10.80 & 10.49 & 0.49 & Sex*, MW* \\
\hline $20: 4$ & 3.24 & 2.93 & 3.54 & 2.70 & 0.54 & \\
\hline
\end{tabular}

a Low market weight; 109.0 and $109.7 \mathrm{~kg}$ on averages in gilts and barrows, respectively.

b High market weight; 132.0 and $126.0 \mathrm{~kg}$ on averages in gilts and barrows, respectively.

a,b Data are means of 24 animals.

WHC, water-holding capacity.

$* \mathrm{P}<0.05 ; * * \mathrm{P}<0.01$.

이들 고정오차의 효과는 크지 않았다.

배최장근(등심)의 $\mathrm{pH}$ 는 $110 \mathrm{~kg}$ 출하 구(5.80) 가 고체중 출하 구(5.64)보다 통계적으로는 높 았으나 $(\mathrm{P}<0.01)$ 두 출하체중간 수치상의 $\mathrm{pH}$ 차 이는 생화학적인 의미를 부여하기에는 작은 수 치였다(Table 3). 근육의 보수력, 명도 $\left(\mathrm{L}^{*}\right)$ 및 적색도 $\left(\mathrm{a}^{*}\right)$ 에서는 성 및 출하체중간 차이가 없 었다. 본 근육의 수분 및 조지방 함량은 성 및 출하체중간 차이가 없었으나 조단백질 함량은 고체중 출하구가 $110 \mathrm{~kg}$ 출하구보다 높았다(22.3 vs. $20.8 \% ; \quad \mathrm{SE}=0.1 \% ; \quad \mathrm{P}<0.01) . \quad$ 배최장근의 palmitic acid(16:0) 함량은 $110 \mathrm{~kg}$ 출하 구가 고 체중 출하 구보다 높았으나(25.85 vs. 24.82\%; $\mathrm{SE}=0.19 \% ; \mathrm{P}<0.01)$ 타 포화지방산[myristic(14:0)
\& stearic(18:0) acids] 함량은 두 성 혹은 출하 체중간 차이가 없었다. 불포화지방산에 있어서 는 palmitoleic(16:1) 및 arachidonic(20:4) acids 함 량은 두 성 혹은 출하체중간 차이가 없었으나, oleic acid(18:1) 함량은 고체중 출하 구가 $110 \mathrm{~kg}$ 출하 구보다 높았다(43.93 vs. $40.94 \%$; $\mathrm{SE}=0.37 \%$; $\mathrm{P}<0.01)$. 또한 linoleic acid(18:2) 함량에 있어서 는 암퇘지가 거세돼지보다 높았고(11.76 vs. $10.64 \%$; $\mathrm{SE}=0.35 \% ; \mathrm{P}<0.05), 110 \mathrm{~kg}$ 출하 구 (11.78\%)가 고체중 출하 구(10.62\%)보다 높았다 $(\mathrm{P}<0.05)$.

Table 4는 등심, 삼겹살 및 뒷다리 부위의 신 선육 및 조리육에 대한 관능평가 결과이다. 등 심 부위 신선육에서는 고체중 출하 구가 $110 \mathrm{~kg}$ 
Table 4. Sensory evaluation on selected fresh and cooked primal cuts

\begin{tabular}{|c|c|c|c|c|c|c|}
\hline \multirow{2}{*}{ Item } & \multicolumn{2}{|c|}{ Gilts } & \multicolumn{2}{|c|}{ Barrows } & \multirow{2}{*}{$\begin{array}{c}\text { Pooled } \\
\text { SE }\end{array}$} & \multirow{2}{*}{ Significance } \\
\hline & Lo MW $^{\mathrm{a}}$ & Hi MW $^{\mathrm{b}}$ & Lo $\mathrm{MW}^{\mathrm{a}}$ & Hi MW $^{\mathrm{b}}$ & & \\
\hline \multicolumn{7}{|c|}{ Loin $^{\mathrm{C}}$} \\
\hline \multicolumn{7}{|l|}{ Fresh meat } \\
\hline Color $^{1)}$ & 5.49 & 5.25 & 4.89 & 5.09 & 0.23 & \\
\hline Aroma $^{1)}$ & 1.87 & 3.98 & 1.78 & 3.67 & 0.13 & $\mathrm{MW}^{* *}$ \\
\hline Off-flavor ${ }^{2)}$ & 1.33 & 2.36 & 1.33 & 2.07 & 0.14 & $\mathrm{MW}^{* *}$ \\
\hline Drip ${ }^{2)}$ & 5.82 & 3.37 & 5.67 & 3.50 & 0.27 & $\mathrm{MW}^{* *}$ \\
\hline Marbling ${ }^{1)}$ & 4.03 & 5.79 & 3.85 & 6.06 & 0.27 & $\mathrm{MW}^{* *}$ \\
\hline Acceptability ${ }^{1)}$ & 5.00 & 5.79 & 4.96 & 6.04 & 0.21 & $\mathrm{MW}^{* *}$ \\
\hline Cooking loss, \% & 37.1 & 27.2 & 37.6 & 25.3 & 1.3 & $\mathrm{MW}^{* *}$ \\
\hline \multicolumn{7}{|l|}{ Cooked meat } \\
\hline Color & 4.86 & 4.73 & 4.76 & 4.84 & 0.24 & \\
\hline Aroma & 1.50 & 1.00 & 1.81 & 1.00 & 0.14 & $\mathrm{MW}^{* *}$ \\
\hline Off-flavor & 0.91 & 0.84 & 0.64 & 0.87 & 0.09 & \\
\hline Juiciness ${ }^{1)}$ & 3.36 & 4.17 & 3.98 & 3.68 & 0.32 & \\
\hline Tenderness ${ }^{1)}$ & 3.32 & 4.30 & 3.66 & 3.90 & 0.34 & \\
\hline Shear force ${ }^{2)}, \mathrm{kg} / \mathrm{cm}^{2}$ & 4.17 & 5.67 & 3.90 & 5.66 & 0.31 & $\mathrm{MW}^{* *}$ \\
\hline Acceptability & 4.55 & 4.79 & 4.86 & 4.53 & 0.24 & \\
\hline \multicolumn{7}{|c|}{ Belly $^{\mathrm{d}}$} \\
\hline Fat score ${ }^{\mathrm{e}}$ & 4.95 & 5.02 & 5.22 & 5.27 & 0.26 & \\
\hline \multicolumn{7}{|l|}{ Cooked meat } \\
\hline Color & 5.22 & 5.72 & 4.68 & 5.56 & 0.24 & $\mathrm{MW}^{*}$ \\
\hline Aroma & 4.93 & 4.85 & 4.94 & 4.92 & 0.18 & \\
\hline Off-flavor & 0.75 & 0.51 & 0.64 & 0.33 & 0.08 & $\mathrm{MW}^{*}$ \\
\hline Juiciness & 4.86 & 5.25 & 4.90 & 5.22 & 0.20 & \\
\hline Acceptability & 5.15 & 5.53 & 5.43 & 5.66 & 0.21 & \\
\hline \multicolumn{7}{|c|}{$\underline{\operatorname{Ham}}^{\mathrm{d}}$} \\
\hline \multicolumn{7}{|l|}{ Cooked meat } \\
\hline Color & 4.49 & 4.36 & 4.55 & 4.73 & 0.23 & \\
\hline Aroma & 3.51 & 2.97 & 3.36 & 3.45 & 0.33 & \\
\hline Off-flavor & 0.56 & 0.48 & 0.42 & 0.50 & 0.09 & \\
\hline Juiciness & 4.01 & 3.79 & 3.99 & 4.54 & 0.44 & \\
\hline Tenderness & 4.11 & 4.30 & 4.47 & 4.73 & 0.48 & \\
\hline Acceptability & 4.60 & 4.28 & 4.61 & 4.54 & 0.39 & \\
\hline
\end{tabular}

a Low market weight; 109.0 and $109.7 \mathrm{~kg}$ on averages in gilts and barrows, respectively.

b High market weight; 132.0 and $126.0 \mathrm{~kg}$ on averages in gilts and barrows, respectively.

c,d Twelve and three animals were evaluated in each sex $\times$ MW combination, respectively, by 10 panelists; experimental unit was animal(sex $\times$ MW).

e Overall score of the inter-muscular fat layers of fresh belly.

1),2) Evaluated according to a 9-point integer scale beginning from 1; Greater scores indicate 'more' and 'less' acceptable sensory responses, respectively.

$* \mathrm{P}<0.05 ; * * \mathrm{P}<0.01$. 
출하 구에 비해 향 및 상강도가 우수하였을 뿐 만 아니라 $(\mathrm{P}<0.01)$ 육즙삼출(drip)도 낮아 $(\mathrm{P}<0.01)$ 비록 불쾌취(off-flavor)는 높았지만 $(\mathrm{P}<0.01)$ 전체 적인 기호도가 높았다 $(\mathrm{P}<0.01)$. 이와는 다소 대 조적으로 고체중 출하 구는 $110 \mathrm{~kg}$ 출하 구에 비해 가열감량이 작았으나 가열육에 있어서는 향이 열등하고 $(\mathrm{P}<0.01)$, 색깔, 다즙성, 불쾌취 및 연도에서는 차이가 없었으며, 기계적인 전 단가는 전자가 후자보다 높아 $(\mathrm{P}<0.01)$ 전체적인 기호도에서 두 출하체중간 차이가 없는 것으로 평가되었다. 삼겹살 신선육의 지방 점수는 두 출하체중 구간 차이가 없었고, 가열육에 있어 서는 고체중 출하 구가 $110 \mathrm{~kg}$ 출하 구에 비해
색깔이 우수하고 불쾌취가 덜 나는 것으로 평 가되었으나 향, 다즙성 및 전체적인 기호도에 서는 두 출하체중 구간 차이가 없었다. 뒷다리 부위 가열육의 경우는 색깔, 향, 불쾌취, 다즙 성, 연도 및 전체적인 기호도에서 두 출하체중 구간 차이가 없는 것으로 평가되었다.

\section{3. '고체중' 출하돈의 수익성}

$110 \mathrm{~kg}$ 에 출하된 암퇘지와 거세돼지는 공히 $95 \%$ 이상 A 혹은 B 도체등급을 받았다(Table 5). 평균 $126 \mathrm{~kg}$ 에 출하된 고체중 거세돼지는 $87.5 \%$ A 혹은 B 등급을 기록함으로써 $110 \mathrm{~kg}$

Table 5. Distribution of carcass grades and marginal profits of the finishing gilts and barrows slaughtered at 'high' market weights vs. $110 \mathrm{~kg}$

\begin{tabular}{|c|c|c|c|c|}
\hline \multirow{2}{*}{ Item } & \multicolumn{2}{|c|}{ Gilts } & \multicolumn{2}{|c|}{ Barrows } \\
\hline & Lo $\mathrm{MW}^{\mathrm{a}}$ & Hi MW $^{\mathrm{b}}$ & Lo $\mathrm{MW}^{\mathrm{a}}$ & Hi MW $^{\mathrm{b}}$ \\
\hline \multicolumn{5}{|l|}{ Distribution of the carcass grade, \% } \\
\hline A-grade & 57.1 & 8.3 & 66.7 & 50.0 \\
\hline B-grade & 38.1 & 4.2 & 33.3 & 37.5 \\
\hline C-grade & - & 50.0 & - & 8.3 \\
\hline D-grade & 4.8 & 37.5 & - & 4.2 \\
\hline \multicolumn{5}{|c|}{ Marginal profit of the Hi-MW pig relative to the Lo-MW pig, won/head } \\
\hline Current grading standard ${ }^{\mathrm{c}}$ & - & $-34,939$ & - & $+3,530$ \\
\hline Hypothetical grading standard ${ }^{\mathrm{c}, \mathrm{d}}$ & - & $+22,307$ & - & $+11,405$ \\
\hline
\end{tabular}

$<$ Calculation of the marginal profit of the $125-\mathrm{kg}$ barrow relative to the $110-\mathrm{kg}$ one $>$

Marginal production cost of the 125-kg barrow

Feed cost: $15 \mathrm{~kg}($ wt gain $) \div 0.22$ (gain:feed) $\times 300$ won $/ \mathrm{kg}($ feed price $)=20,455$ won

Other cost: $15 \mathrm{~kg} \div 0.8 \mathrm{~kg} / \mathrm{d}(\mathrm{ADG}) \times 200$ won $/ \mathrm{d}($ other daily cost $)=3,750$ won

Marginal profit of the $125-\mathrm{kg}$ pig under the current carcass grading standard

Earnings from a 110-kg pig: $110 \mathrm{~kg} \times 0.75 \times 3,165.4 \mathrm{won} / \mathrm{kg}($ avg price $)=261,146$ won

Earnings from a $125-\mathrm{kg}$ pig: $125 \mathrm{~kg} \times 0.75 \times 3,081.4 \mathrm{won} / \mathrm{kg}($ avg price) $=288,881$ won

Marginal profit: 288,881 - 261,146 - 20,455(feed cost) - 3,750(other cost) = 3,530 won

Marginal profit of the $125-\mathrm{kg}$ pig under the hypothetical carcass grading standard

Earnings from a $125-\mathrm{kg}$ pig: $125 \mathrm{~kg} \times 0.75 \times 3,165.4$ won $/ \mathrm{kg}($ avg price $)=296,756$ won

Marginal profit: 296,756 - 261,146 - 20,455(feed cost) - 3,750(other cost) $=11,405$ won

${ }^{\mathrm{a}}$ Low market weight; 109.0 and $109.7 \mathrm{~kg}$ on averages in gilts and barrows, respectively.

${ }^{\mathrm{b}}$ High market weight; 132.0 and $126.0 \mathrm{~kg}$ on averages in gilts and barrows, respectively.

c Conditions: Target weights of the Hi MW are 135 and 125kg in gilts and barrows, respectively; gain:feed, ADG and dressing percentage are $0.22,0.8 \mathrm{~kg}$ and $75 \%$, respectively; prices of A-, B-, C- and D-grade gilt and barrow carcass pairs are 3,893 \& 3,268, 3,346 \& 2,960, 3,056 \& 2,742 and 2,970 \& 2614 won (2007. 2. 14 market prices), respectively.

d Premise: The upper weight limits of the A- and B-grade carcasses of the current carcass grading standard are not applied and also distribution of the carcass grades of the Hi-MW pigs is identical to that of the Lo-MW pigs. 
출하돈 대비 단지 소폭으로 도체등급이 저하된 반면 평균 $132 \mathrm{~kg}$ 에 출하된 고체중 암퇘지는 87.5\% C 혹은 D 등급 도체로 전락함으로써 생 체중 $126 \mathrm{~kg}$ 보다 큰 돼지는 과체중으로 말미암 아 도체등급이 급격히 저하됨을 본 도체등급 판정 결과는 보여주었다. 따라서 2007년 2월 도체가를 기준으로 $110 \mathrm{~kg}$ 출하 대비 $135 \mathrm{~kg}$ 에 출하된 암퇘지는 두당 약 35,000원의 손실이 발생하였으나 $125 \mathrm{~kg}$ 에 출하된 거세돼지는 약 3,500 원/두의 추가수익이 발생한 것으로 추정되 었다. 그러나 도체등급별 도체중 상한선이 설 정된 현행 도체등급 판정 기준이 철폐되어 고 체중 출하돈이 $110 \mathrm{~kg}$ 출하돈과 같은 도체등급 을 받는다는 조건하에서 고체중 출하돈의 수익 성을 계산하면 $110 \mathrm{~kg}$ 출하돈 대비 $135 \mathrm{~kg}$ 암퇘 지와 $125 \mathrm{~kg}$ 거세돼지는 각각 약 22,000원과 11,000 원의 한계수익이 발생할 수 있을 것으로 추정되었다(Table 5).

\section{IV. 고 찰}

선행연구(이 등, 2006)의 결과에서와 같이 본 연구에서도 생체중 약 $90 \mathrm{~kg}$ 부터 $125 \sim 135 \mathrm{~kg}$ ‘고체중'까지 비육한 암퇘지와 거세돼지는 관행 대로 $110 \mathrm{~kg}$ 까지 비육한 돼지에 비해 일당증체 량에는 차이가 없었고, 일당사료섭취량은 고체 중 출하 구와 거세돼지 구가 각각 $110 \mathrm{~kg}$ 출하 구 및 암퇘지 구보다 높았다. 그러나 사료효율 은 두 출하체중 구간 유의차가 없어 $130 \mathrm{~kg}$ 출 하 시 본 변수의 값이 다소 저하되었던 선행연 구의 결과와는 약간의 차이를 나타냈다. 등지 방두께는 선행연구의 결과에서와 같이 고체중 출하 구가 $110 \mathrm{~kg}$ 출하 구보다 높았다. 이와는 약간 대조적으로 선행연구에서는 거세돼지가 암퇘지보다 등지방두께가 높았으나 본 연구에 서는 두 성간의 유의차는 검출되지는 않았다. 한편 선행연구 결과 $135 \& 125 \mathrm{~kg}$ 암퇘지와 거 세돼지의 등지방두께는 각각 22.5 \& $24.0 \mathrm{~mm}$ 내외가 될 것으로 예측되었으나 본 연구 결과 암퇘지는 예측치보다 다소 높은 수치 $(23.7 \mathrm{~mm})$ 를 보인 반면 거세돼지는 예측치보다 다소 낮 은 수치 $(22.5 \mathrm{~mm})$ 를 기록하였다.
Table 6는 본 연구, 선행연구(이 등, 2006) 및 본 연구진의 제 3 의 경남 지역 고체중 비육돈 사양실험(이 등, 2007)의 결과를 종합하여 농장 간 변이를 고정오차에서 제외시키고 성, 출하 체중 및 성 $\times$ 출하체중의 상호작용만을 고정오 차로 삽입한 통계모델 하에서 분석한 결과이 다. 일당증체량은 거세돼지에서는 고체중 출하 구가 $110 \mathrm{~kg}$ 출하 구보다 다소 낮았으나 $(0.87$ vs. $0.82 \mathrm{~kg} ; \mathrm{P}<0.01)$ 암퇘지에서는 두 출하체중 간 차이가 없었다 $(0.78$ vs. $0.80 \mathrm{~kg})$. 일당사료섭 취량은 거세돼지가 암퇘지보다 다소 높았고 (3.34 vs. $3.11 \mathrm{~kg} ; \mathrm{P}<0.01)$, 사료효율은 두 성간 혹은 출하체중간 차이가 없었다. 이와 같이 사 료효율 결과가 일당증체량 및 일당사료섭취량 결과와 다소 일치하지 않는 것은 전자의 계산 상의 특성에 기인하는 것으로 사료된다. 즉 사 료효율은 증체량을 사료섭취량으로 나눈 수치 이기 때문에 두 개의 변수가 관여되는 고로 개 체간의 변이가 커져 실험구간 유의적이 차이가 없을 가능성이 커지기 때문이다. $110 \mathrm{~kg}(110 \mathrm{~kg}$ 출하 구) 및 $130 \mathrm{~kg}$ (고체중 출하 구) 생체중 보 정 등지방두께는 거세돼지가 암퇘지보다 높았 고(23.0 vs. $19.9 \mathrm{~mm} ; \mathrm{P}<0.01)$, 고체중 출하 구가 $110 \mathrm{~kg}$ 출하 구보다 높았다(23.4 vs. $19.4 \mathrm{~mm}$; $\mathrm{P}<0.01)$. 이상과 같이 거세돼지가 암퇘지에 비 해 사료섭취량과 등지방두께가 높았던 본 연구 결과는 이미 잘 알려진 사실과도 일치한다 (Field, 1971). 일괄하여 이상의 결과는 경남 지 역의 대표적인 비육돈은 고도의 적육형 계통이 기 때문에 고체중 출하돈은 관행의 $110 \mathrm{~kg}$ 출 하돈에 비해 등지방두께는 소비자가 선호하는 방향으로 증가되고 성장효율은 우려할 만큼 저 하되지 않는 것으로 평가될 수 있다.

본 연구결과는 물론 선행연구 및 세 연구의 통합결과에서도 공통적으로 도체율은 고체중 출하 구가 $110 \mathrm{~kg}$ 출하 구보다 높아 생체중이 커지면 머리와 내장 등으로 제거되는 비율이 작아져 도체율이 높아지는 것을 알 수 있고, 총 부분육 수율은 암퇘지가 거세돼지보다 높았 는데 이는 일차적으로 부분육 절단 시 전자가 후자보다 제거되는 지방 비율이 낮기 때문이 다. 한편 본 연구에서 도체율은 암퇘지가 거세 
Table 6. Effects of 'high' market weights on growth performance, yields of primal cuts and physicochemical characteristics of the longissimus muscle (loin): pooled results obtained from three studies including the present one

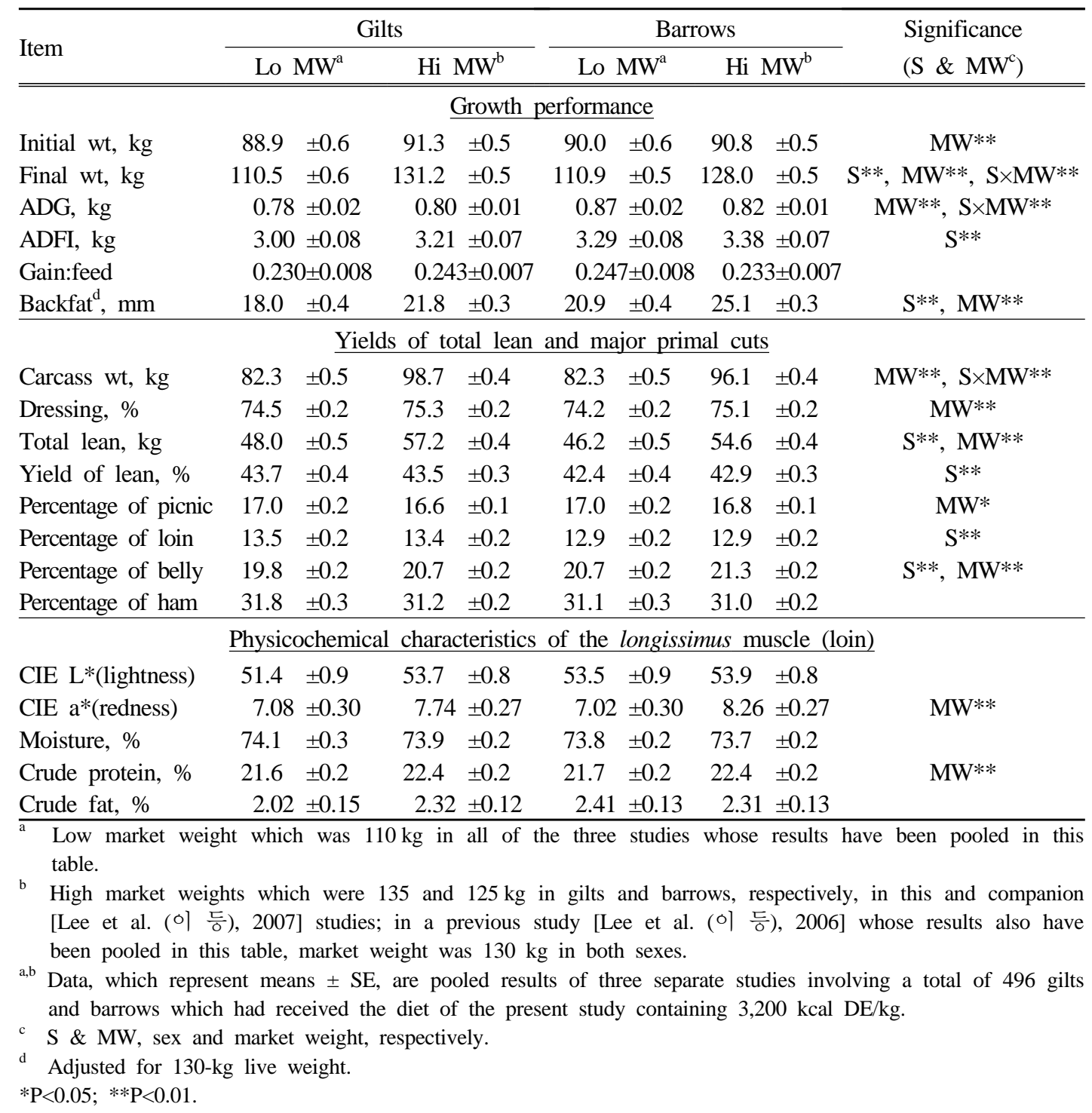

돼지보다 높았고, 총부분육수율은 고체중 출하 구가 $110 \mathrm{~kg}$ 출하 구보다 높았으나 선행연구와 세 연구의 통합결과에서는 이들 성 혹은 출하 체중간 차이가 발견되지 않아 이 부분에 대해 서는 추가적으로 조사해볼 가치가 있을 것으로 사료된다. 그러나 수치상으로 도체율과 총부분 육수율은 본 연구와 선행연구에서 공히 전 실 험구에서 각각 $74 \sim 76 \%$ 및 $42 \sim 45 \%$ 의 좁은 범 위내에 들었기 때문에 두 성 혹은 출하체중간
이들 변수상의 차이가 실질(경제)적인 손익에 미칠 수 있는 영향은 크지 않았다. 같은 맥락 에서 총부분육 중량 대비 각각의 부분육 중량 비율 또한 세 연구의 결과에 따라 성 혹은 출 하체중간 유의적인 차이가 있었으나 수치상으 로 눈에 띨 만큼 차이나는 경우는 없었다. 실 예로 본 연구에서는 삼겹살 비율이 두 성 혹은 출하체중간 차이가 없었으나 선행연구와 세 연 구의 통합결과에서는 거세돼지 및 고체중 출하 
돈이 각각 암퇘지 및 $110 \mathrm{~kg}$ 출하돈보다 높았 지만 수치상의 차이는 $0.7 \sim 1.2 \%$ 범위에 불과 하였다. 따라서 출하체중 증가로 인하여 국내 소비자가 가장 선호하는 삼겹살의 수율은 약간 증가하거나 최소한 감소하지는 않음을 이상의 결과로부터 확인할 수 있다.

PSE(pale, soft, exudative) 이상육 판정의 기준 이 되는 근육의 $\mathrm{pH}$, 명도( $\left.\mathrm{L}^{*}\right)$ 및 보수력 등 (Warner 등, 1997; Joo 등, 1999)은 선행연구(이 등, 2006)에서와 같이 성 혹은 출하체중간 가시 적인 차이가 발견되지 않았고 모든 실험구에서 정상육 범주의 수치가 관찰되었다. 근육의 색 깔에서 주목할만한 것은 본 연구와 선행연구에 서는 성 혹은 출하체중간 적색도상의 차이가 없었으나 세 연구의 통합결과에서는 고체중 출

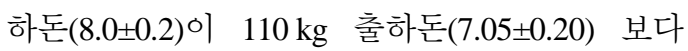
근육의 적색도가 높았다. 즉 이와 같은 결과는 출하체중을 증가시킴으로써 소비자가 선호하는 식육의 붉은 색상을 향상시킬 수 있음을 의미 한다. 일반적으로 근육의 적색도는 myoglobin 함량에 비례하는데 육성 - 비육돈 근육의 myoglobin 함량은 생체중 증가와 더불어 증가하는 것으로 알려져 있다(Martin 등, 1980; Latorre 등, 2004).

근육의 수분 및 조지방 함량은 본 연구와 선 행 연구에서 공히 성 혹은 출하체중간 차이가 없었으나 조단백질 함량은 본 연구에서만 고체 중 출하돈이 $110 \mathrm{~kg}$ 출하돈보다 높았다. 현재로 서는 두 연구간 상대적인 조단백질 함량의 차 이에 대한 결정적인 원인은 알 수 없으나 두 연구에 사용됐던 공시돈의 부계의 유전적 배경 이 다소간 달랐던 것이(모계는 동일) 가능한 이 유 중의 하나로서 이 부분에 대해서는 추가의 연구가 요망된다. 또한 근육의 지방산 조성에 있어서도 몇몇 지방산 비율은 성과/혹은 출하 체중간 차이가 있었으나 선행연구(이 등, 2006) 결과와 일치하지 않아 이 부분 역시 명확한 결 론을 내리기 위해서는 추가의 연구가 필요하 다.

관능평가에 있어서 등심부위 신선육은 고체 중 출하 구가 $110 \mathrm{~kg}$ 출하 구에 비해 비록 불 쾌취는 높았으나 육즙삼출이 낮고 향과 상강도 는 물론 전체적인 기호도가 높아 육질 면에서
고체중 사육의 긍정적 면을 보여주었다. 또한 보수성과 지방을 유지하는 능력이 큰 고기일수 록 다즙성이 좋을 뿐만 아니라(Carlin과 Harrison, 1978; Risvik, 1994) 고체중 출하 구가 $110 \mathrm{~kg}$ 출하 구에 비해 등심의 가열감량도 낮 았기 때문에 전자가 후자에 비해 다즙성이나 전체적인 기호도도 높을 것으로 기대되었으나 등심은 물론 삼겹살과 뒷다리 가열육에서 이들 두 관능 평가 변수에 대한 출하체중 구간 차이 가 없었다. 한편 $110 \mathrm{~kg}$ 출하돈 대비 고체중 출 하돈 등심의 전단가 증가는 생체중 증가에 수 반되는 결체조직 함량의 증가에 기인하였던 것 으로 추정된다.

$110 \mathrm{~kg}$ 대비 평균 $132 \mathrm{~kg}$ 에 출하된 고체중 암 퇘지는 선행연구(이 등, 2006)에서와 같이 과체 중으로 말미암아 도체등급이 낮아져 많은 손실 을 유발하였으나 만일 현행 A \& B 도체등급의 도체중 상한선이 철폐되어 $125 \sim 135 \mathrm{~kg}$ 고체중 출하돈이 $110 \mathrm{~kg}$ 출하돈과 같은 등급을 받을 수 있다면 고체중 비육돈 생산이 $110 \mathrm{~kg}$ 비육 돈 생산보다 훨씬 더 수익성이 클 것으로 추산 되었다. 반면 평균 $126 \mathrm{~kg}$ 에 출하된 거세돼지에 서는 $130 \sim 135 \mathrm{~kg}$ 고체중 암퇘지에서와는 달리 $110 \mathrm{~kg}$ 출하돈에 비해 두당 3,000원 이상의 추 가수익이 발생한 것으로 추산되었다. 이는 현 행 도체등급 판정 기준 하에서도 $125 \mathrm{~kg}$ 수준 까지는 출하체중 $110 \mathrm{~kg}$ 보다는 그 이상일 때 수익이 커 질 수 있음을 시사한다.

결론적으로 경남지역의 대표적인 비육돈은 고도의 적육형 계통이기 때문에 현행 도체등급 판정 기준 하에서도 $110 \mathrm{~kg}$ 보다는 $120 \sim 125 \mathrm{~kg}$ 에 출하돼야 소비자의 기호에 더 잘 부응할 수 있고 농가 수익은 $110 \mathrm{~kg}$ 출하 시와 동등 혹은 다소 향상될 수도 있을 것으로 사료된다. 더욱 바람직하게는 현행 A \& B 등급의 도체중 허용 범위가 철폐되거나 '고체중' 도체를 수용할 수 있도록 상향 조정되어야 하고, 이 경우 선행연 구(이 등, 2006)의 결론에서와 같이 암퇘지와 거세돼지의 출하체중은 각각 $135 \& 125 \mathrm{~kg}$ 이 적정 수준일 것으로 예측된다. 이와 같은 주장 의 다른 이유로는 우리나라는 다른 나라에 비 해 이유자돈 생산비가 높아 도살체중이 커질수 
록 이유자돈 생산비가 희석될 수 있기 때문이 다. 아울러 전국에서 사육되고 있는 돼지의 유 전적인 배경이 비슷하기에 본 연구의 결과는 경남지역의 돼지에 국한되지 않을 것으로 사료 된다. 또한 앞으로 개정될 육질등급 판정 기준 안에는 육질등급 2차 판정 시 삼겹살의 근내지 방두께, 삼겹살두께 및 지방피복상태 등의 기 준이 포함되는데 본 지면에 소개한 바와 같이 고체중 출하돈의 삼겹살 지방피복상태, 수율 및 기호성이 $110 \mathrm{~kg}$ 출하돈에 비해 동등 혹은 그 이상의 수치를 나타냈기 때문에 이 또한 농 가 수익 향상에 일조할 수 있을 것으로 기대된다.

\section{V. 요 약}

국내에서 비육돈은 평균적으로 $110 \mathrm{~kg}$ 에 출 하되고 있으나 국내 대부분의 비육돈은 적육형 계통이기 때문에 도체 품질을 저하시키지 않고 출하체중을 $120 \mathrm{~kg}$ 이상 증가시킬 수 있는 가 능성이 높다. 본 실험은 '고체중' 비육돈의 성 장효율과 수익성 및 도체의 이화학적 특성과 소비자의 관능적 수용성을 조사하고자 수행되 었다. (Yorkshire $\times$ Landrace) $\times$ Duroc 3원 교잡 종 암퇘지와 거세돼지 총 96두를 16돈방에서 체중 $90 \mathrm{~kg}$ 시부터 비육후기 사료를 무제한 급 여하고 $110 \mathrm{~kg}$ (대조구) 혹은 고체중(암퇘지와 거세돼지 각각 $135 \& 125 \mathrm{~kg}$ )에 도살하여 도체 를 분석하였다. 일당사료섭취량은 거세돼지와 고체중 출하 구가 각각 암퇘지와 $110 \mathrm{~kg}$ 출하 구보다 높았으나 $(\mathrm{P}<0.01)$ 일당증체량과 사료효 율은 두 출하체중 구간 차이가 없었다. $135 \mathrm{~kg}$ 및 $125 \mathrm{~kg}$ 생체중에 보정된 암퇘지와 거세돼지 의 등지방두께는 각각 $23.7 \& 22.5 \mathrm{~mm}$ 로서 각 각 성의 $110 \mathrm{~kg}$ 출하체중 구의 수치 $(19.7$ \& $21.1 \mathrm{~mm})$ 보다 높았다 $(\mathrm{P}<0.01)$. 등심을 제외한 부분육 수율은 두 성 혹은 출하체중간 통계적 인 차이는 있었으나 $(\mathrm{P}<0.05)$ 수치상의 차이는 비교적 작았다. 등심의 단백질 함량은 고체중 출하 구가 $110 \mathrm{~kg}$ 출하 구보다 높았으나 $(\mathrm{P}<0.01)$, 조지방과 수분 함량 및 색깔 등과 같 은 이화학적 특성은 성 혹은 출하체중간 차이 가 없었다. 관능평가에서 등심부위 신선육의
향, 상강도 및 전체적인 기호도는 고체중 출하 구가 $110 \mathrm{~kg}$ 출하 구보다 높았으나 $(\mathrm{P}<0.01)$ 등 심, 삼겹살 및 뒷다리 가열육에 대한 기호도에 서는 두 출하체중 구간 차이가 없었다. 현행 도체등급 판정 기준 및 도체 가격 하에서 $110 \mathrm{~kg}$ 대비 $135 \& 125 \mathrm{~kg}$ 암퇘지와 거세돼지는 각각 두당 약 $-35,000$ 원 및 3,500원의 한계수 익이 발생하나 만일 A \& B 등급의 도체중 상 한선을 적용하지 않는 조건으로 계산하면 고체 중 암퇘지와 거세돼지는 각각 두당 약 22,000 원 및 11,000원의 한계수익이 발생할 수 있을 것으로 추산되었다. 이상의 결과를 종합하면, 현행 도체등급 판정 기준 하에서도 $120 ~ 125$ $\mathrm{kg}$ 출하돈이 $110 \mathrm{~kg}$ 출하돈보다 소비자의 기호 에 더 잘 부응할 수 있고 수익은 후자와 동등 혹은 다소 향상될 수도 있을 것으로 사료된다. 더욱이 현행 A \& B 등급의 도체중 허용범위가 철폐되거나 ‘고체중' 도체를 수용할 수 있도록 상향조정되기만 한다면 본 실험에서 설정했던 암퇘지와 거세돼지의 표적체중 즉 135 \& 125 $\mathrm{kg}$ 이 적정수준일 것으로 예측된다.

$$
\text { VI. 사 사 }
$$

본 연구는 산업자원부와 한국산업기술평가원 이 지원하는 진주산업대학교 동물생명산업센터 의 사업비 지원으로 수행되었습니다. 본 논문 의 저자들은 도체분석 및 관능평가에 참여한 경상대학교 식육과학실험실 여러 분들에게 깊 은 감사를 드립니다.

\section{VII. 인 용 문 헌}

1. AOAC. 1990. Official Methods of Analysis. 15th ed. Association of Official Analytical Chemists. Arlington, VA, USA.

2. Carlin, A. F. and Harrison, D. L. 1978. Cooking and sensory methods used in experimental studies on meat. National Livestock and Meat Board, Chicago, IL, USA.

3. CIE. 1978. Recommendations on uniform color spaces-color difference equations, psychometric 
color terms. Supplements no. 2 to CIE Publication No. 15 (E-1.3.1) 1971/(TC-1-3). Commission Internationale de l'Eclairage, Paris.

4. Field R. A. 1971. Effect of castration on meat quality and quantity. J. Anim. Sci. 32:849-858.

5. Folch, J., Lees, M. and Sloane-Stanley, G. H. 1957. A simple method for the isolation and purification of total lipids from animal tissues. J. Biol. Chem. 226:497-500.

6. Joo, S. T., Kauffman, R. G., Kim, B. C. and Park, G. B. 1999. The relationship of sarcoplasmic and myofibrillar protein solubility to colour and water-holding capacity in porcine longissimus muscle. Meat Sci. 52:291-297.

7. Kim, Y. S., Kim, S. W., Weaver, M. A. and Lee, C. Y. 2005. Increasing the pig market weight: world trends, expected consequences and practical considerations. Asian-Aust. J. Anim. Sci. 18:590600 .

8. Latorre, M. A., Lazaro, R., Valencia, D. G., Medel, P. and Mateos, G. G. 2004. The effects of gender and slaughter weight on the growth performance, carcass traits and meat quality characteristics of heavy pigs. J. Anim. Sci. 82: 526-533.

9. Lee, C. Y., Lee, H. P., Jeong, J. H., Baik, K. H., Jin, S. K., Lee, J. H. and Sohn, S. H. 2002. Effects of restricted feeding, low-energy diet, and implantation of trenbolone acetate plus estradiol on growth, carcass traits, and circulating concentrations of insulin-like growth factor (IGF)-I and IGF-binding protein-3 in finishing barrows. J. Anim. Sci. 80:84-93.

10. Martin, A. H., Sather, A. P., Fredeen, H. T. and Jolly, R. W. 1980. Alternative market weights for swine. II. Carcass composition and meat quality. J. Anim. Sci. 50:699-705.

11. NASS. 2006. Agricultural Statistics. USDA. National Agricultural Statistics Service. US Government Printing Office, Washington, D.C.

12. Risvik, E. 1994. Sensory properties and preference. Meat Sci. 36:67-77.

13. SAS. 1996. SAS User's Guide: Statistics, SAS Inst., Inc., Cary, NC, USA.

14. Warner, R. D., Kauffman, R. G. and Greaser, M. L. 1997. Muscle protein changes post mortem in relation to pork quality traits. Meat Sci. 45:339352.

15. Zanardi, E., Novelli, E., Ghiretti, G. P. and Chizzolini, R. 2000. Oxidative stability of lipids and cholesterol in salame Milano, coppa and Parma ham: dietary supplementation with vitamin E and oleic acid. Meat Sci. 55:169-175.

16. 이철영, 권오천, 하덕민, 신호원, 이제룡, 하영주, 이진희, 하승호, 김원기, 김광위, 김두환. 2006. $110 \mathrm{~kg}$ 대비 $130 \mathrm{~kg}$ 에 도축된 비육돈의 성장효 율, 도체 품질 특성 및 수익성. 한국동물자원과 학회지 48:493-502.

17. 이철영, 김민호, 하덕민, 박재완, 오관용, 이제룡, 하영주, 박병철. 2007. 비육후기 사료의 에너지 수준이 ‘고체중' 출하돈의 성장효율 및 도체특성 에 미치는 영향. 한국동물자원과학회지 49:471480.

18. 진상근, 김일석, 김수정, 정기종, 고병순, 남영욱, 문성실. 2007. 생균제 급여가 재래돼지와 멧돼지 의 교배에 의해 브랜드화 된 돈육의 물리화학적 및 관능적 특성 비교. 한국동물자원과학회지 49: 99-108.

(접수일자 : 2007. 4. 5. / 채택일자 : 2007. 8. 6.) 